\title{
Effectiveness of a Computerized Interactive Book in Developing the Visual Thinking Skills in Technology for the Fifth Grade Male Students in Gaza
}

\author{
Ahmad A. Abu Zaydah \\ M.ED. \\ Palestinian Mministry of Education \\ Palestine, Gaza Strip, Jabalia
}

\author{
Hatem Y. Abu Zaydah \\ PH.D \\ Almustaqbal Research Center \\ Gaza Strip - Palestine
}

\begin{abstract}
This study aimed to investigate the effectiveness of using the computerized interactive book in the development of visual thinking skills in Technology for the fifth grade male students in Gaza. The researchers adopted the experimental approach. The sample of the study consisted of four classes which reached 120 male students, they randomly chose two classes of them to present the experimental group with 60 male students who studied by using computerized interactive book while the traditional method was used with the control group with the rest of the students 60 . The researchers ascertained the equivalence of the two groups in chronological age, general achievement, previous achievement in Technology, and results of pre-test of visual thinking skills which was prepared by the researchers. The results indicate that no significant differences were found between the experimental and control groups in the visual thinking pretest results in addition to no significant differences were found between mean scores of high achievers at the experimental and control groups in the visual thinking pretest, also there is no significant differences found between mean scores of low achievers at the experimental and control groups in the visual thinking pretest. The computerized interactive book is effective in developing the visual thinking skills.
\end{abstract}

\section{General Terms}

Computerized Interactive Book contains several visual thinking skills, The fifth grade male students.

\section{Keywords}

Computerized Interactive Book, Visual thinking skills, Technology education, The fifth grade male students

\section{INTRODUCTION}

In the light of technological development, which haunts us today, the use of computers in education become a necessity that we couldn't ignore it at all, and the role of the teacher changed from traditional aspect to a professional role that associated with technological development [1]. With the advent of various types of tablet computers are used, including laptops, iPads and Android Tablets. These individual portable digital devices can be used as e-book readers to support mobile personalized learning[2], This came at a time of rising of interactive technologies provides a chance to expand learners informal learning opportunities in a new direction, with the potential to support learners physical, social, and cognitive development[3].Among the advantages of teaching with such interactive books is the possibility offered to the student to participate actively during the lesson and make correlations and creative comparisons with either other lessons or other courses, thus supporting the interdisciplinary learning approach[4].

The movement toward instruction supported by computerbased technology is all taking place in the midst of a major shift in the publishing industry where many book sellers are beginning to actively promote electronic books (e-books) and e-book readers as a less expensive and more efficient method to read[5].

The PC magazine encyclopedia defined the computerized interactive book (E-BOOK) as an electronic counterpart of a printed book, which can be viewed on a desktop computer, laptop, smartphone or e-book reader [6], Moreover Živković defined the computerized interactive book as a software application for use on a standard-sized computer or a booksized computer used solely as a reading device[7]. These books allow users to automatically adjust the rendering of multimedia pages at different resolutions on terminal units[8].The computerized interactive book consists of huge number of pictures, diagrams, symbols, signs, shapes and videos which are tools of the visual thinking. The computerized interactive book has some advantages over printed books. According to them, the most extending advantages of e-books were their being easy to share and organize. Additionally, most of the participants admitted that e-books are environment friendly[9][10].

Teaching thinking becomes an urgent necessity imposed by the current time, and interest is no longer confined to efforts to help students to gain knowledge ,information , facts and educational concepts, but it goes beyond their mental abilities to develop thinking skills. One of the most important thinking skills is the visual thinking skills that depends on pictures, diagrams, shapes, videos and animations that connect the eye with the brain processes, in addition to imaginations and pictures creation. In general, this objects represents multimedia display.

The visual system may also contain separate subsystems for mental imagery and image rotation. Image rotation skills appear to be located on the right side of the brain, whereas visual imagery is in the left rear of the brain[11].

In view of the current world and the transition from industrial society to information society, the traditional textbooks submitted to test in light of their inability to provide everything published by the researchers, an urgent necessity that these textbooks keep up its place in the field of development of information and communication technology, especially after the image culture control over all communication and information technology. 
We ask that authors follow some simple guidelines. In essence, we ask you to make your paper look exactly like this document. The easiest way to do this is simply to download the template, and replace the content with your own material.

\section{METHODS}

\subsection{Participants and population}

Since more than a decade, the successive technological developments which entered all aspects of the educational process in Gaza Strip and change it for the better, not only in UNRWA institutions, but also in the Palestinian ministry of education through modern education techniques which were brought to them. The responsible authorities estimated the census of public education phase nearly 1136739 [12] children studying at UNRWA and Palestinian ministry of education schools.

This study was conducted with a purposive sample of 60 male students as experimental group and 60 male students as control group. Pretests were performed before the learning using the computerized interactive book. Posttests were also administered to both the experimental and control groups.

The computerized interactive book was presented by using the computer laboratory individually for each student, in addition to using the LCD screen for all the students in the classroom. Various individual and collaborative learning strategies were applied during the course.

\section{Materials}

The researchers constructed study materials and tools which are represented in content analysis for the 4th unit of technology book of the fifth grade, in addition to visual thinking skill list, and a list of criteria of designing a computerized interactive book that includes pedagogical and technical standards in order to design a computerized interactive book. The researchers have prepared a test for visual thinking skills which consist of (38) items, and teacher's guide for using a computerized interactive book in teaching.

\subsection{Statistical analysis}

After collecting the results, the researchers used Independent Sample T-test in order to measure the differences between the mean score of the experimental and control groups, in addition to compute Eta-Square to identify the effect size of the computerized interactive book in development of visual thinking skills. And the researchers used Mann-Whitney- U Test in order to measure the differences between mean scores of high achievers students in both groups, as well as the mean scores of low achievers students. All previous results were treated by using The Statistical Package for Social Sciences (SPSS).

\section{3. RESULTS}

\subsection{Significant differences between experimental and control groups in visual thinking pre-test}

To ensure the equivalence between the experimental and control groups in the visual thinking test, $t$-test was performed. No significant differences were found ( $\mathrm{p}$ values $>$ $0.05)$
Table 1. Significant differences between the experimental and control groups in the visual thinking pre-test.

\begin{tabular}{|c|l|c|c|c|c|c|}
\hline Var. & \multicolumn{1}{|c|}{ Group } & N & Mean & S. D. & t & Stat. sig. \\
\hline \multirow{2}{*}{$\begin{array}{c}\text { Pre- } \\
\text { test }\end{array}$} & $\begin{array}{l}\text { Exper. } \\
\text { group }\end{array}$ & 60 & 10.73 & 5.7 & \multirow{2}{*}{0.16} & $\begin{array}{c}\text { No } \\
\text { signif- } \\
\text { icant }\end{array}$ \\
\cline { 2 - 5 } & Cont. group & 60 & 10.90 & 5.4 & & \multicolumn{2}{|c|}{} \\
\hline
\end{tabular}

\subsection{Significant differences in visual thinking post-test}

T-test was used to determine the differences at the visual thinking skills in the posttest. The results indicate significant differences in all the visual thinking skills in addition to the total degree $(\mathrm{p}<0.001)$.

Table 2. Significant differences between the experimental and control groups in the visual thinking post-test

\begin{tabular}{|c|c|c|c|c|c|c|}
\hline $\begin{array}{c}\text { Visual } \\
\text { thinking } \\
\text { skills } \\
\end{array}$ & Group & $\mathbf{N}$ & Mean & $\begin{array}{l}\text { S. } \\
\text { D. }\end{array}$ & $\mathbf{t}$ & $\begin{array}{c}p \\
\text { value } \\
\text { (sig.) }\end{array}$ \\
\hline \multirow{2}{*}{$\begin{array}{l}\text { Shape } \\
\text { Recognition } \\
\text { Skill }\end{array}$} & $\begin{array}{l}\text { Exper. } \\
\text { Group }\end{array}$ & 60 & 8.0 & 2.0 & \multirow{2}{*}{8.9} & \multirow{2}{*}{$<0.01$} \\
\hline & $\begin{array}{c}\text { Control } \\
\text { Group }\end{array}$ & 60 & 4.7 & 2.0 & & \\
\hline \multirow{2}{*}{$\begin{array}{l}\text { Visual } \\
\text { discrimination } \\
\text { skill }\end{array}$} & $\begin{array}{l}\text { Exper. } \\
\text { Group }\end{array}$ & 60 & 5.4 & 1.5 & \multirow{2}{*}{$\begin{array}{c}11 . \\
2\end{array}$} & \multirow{2}{*}{$<0.01$} \\
\hline & $\begin{array}{l}\text { Control } \\
\text { Group }\end{array}$ & 60 & 2.4 & 1.3 & & \\
\hline \multirow{2}{*}{$\begin{array}{l}\text { Visual } \\
\text { information } \\
\text { interpreting } \\
\text { skill } \\
\end{array}$} & $\begin{array}{l}\text { Exper. } \\
\text { Group }\end{array}$ & 60 & 3.2 & 1.0 & \multirow{2}{*}{6.7} & \multirow{2}{*}{$<0.01$} \\
\hline & $\begin{array}{l}\text { Control } \\
\text { Group }\end{array}$ & 60 & 1.6 & 1.4 & & \\
\hline \multirow{2}{*}{$\begin{array}{l}\text { The spatial } \\
\text { relationship } \\
\text { recognize skill }\end{array}$} & $\begin{array}{l}\text { Exper. } \\
\text { Group }\end{array}$ & 60 & 3.6 & 0.6 & \multirow{2}{*}{6.5} & \multirow{2}{*}{$<0.01$} \\
\hline & $\begin{array}{l}\text { Control } \\
\text { Group }\end{array}$ & 60 & 2.5 & 1.1 & & \\
\hline \multirow{2}{*}{$\begin{array}{l}\text { Shape } \\
\text { analysis skill }\end{array}$} & $\begin{array}{l}\text { Exper. } \\
\text { Group }\end{array}$ & 60 & 2.2 & 0.9 & \multirow{2}{*}{8.2} & \multirow{2}{*}{$<0.01$} \\
\hline & $\begin{array}{l}\text { Control } \\
\text { Group }\end{array}$ & 60 & 0.8 & 0.8 & & \\
\hline \multirow{2}{*}{$\begin{array}{l}\text { Recognize the } \\
\text { mystery and } \\
\text { decoding } \\
\text { optical } \\
\text { illusion skill }\end{array}$} & $\begin{array}{l}\text { Exper. } \\
\text { Group }\end{array}$ & 60 & 3.1 & 0.9 & \multirow[b]{2}{*}{9.5} & \multirow[b]{2}{*}{$<0.01$} \\
\hline & $\begin{array}{l}\text { Control } \\
\text { Group }\end{array}$ & 60 & 1.2 & 1.2 & & \\
\hline \multirow{2}{*}{$\begin{array}{l}\text { Construction } \\
\text { and } \\
\text { configuration } \\
\text { skill }\end{array}$} & $\begin{array}{l}\text { Exper. } \\
\text { Group }\end{array}$ & 60 & 2.2 & $\begin{array}{c}0.98 \\
5\end{array}$ & \multirow{2}{*}{$\begin{array}{l}7.5 \\
68\end{array}$} & \multirow{2}{*}{$<0.01$} \\
\hline & $\begin{array}{l}\text { Control } \\
\text { Group }\end{array}$ & 60 & 0.8 & $\begin{array}{c}0.99 \\
3 \\
\end{array}$ & & \\
\hline \multirow{2}{*}{$\begin{array}{l}\text { Extracting } \\
\text { meanings skill }\end{array}$} & $\begin{array}{l}\text { Exper. } \\
\text { Group }\end{array}$ & 60 & 2.0 & $\begin{array}{c}0.89 \\
2\end{array}$ & \multirow{2}{*}{$\begin{array}{l}9.0 \\
26\end{array}$} & \multirow{2}{*}{$<0.01$} \\
\hline & $\begin{array}{l}\text { Control } \\
\text { Group }\end{array}$ & 60 & 0.6 & $\begin{array}{c}0.80 \\
4\end{array}$ & & \\
\hline \multirow{2}{*}{ Total Scores } & $\begin{array}{l}\text { Exper. } \\
\text { Group }\end{array}$ & 60 & 29.9 & $\begin{array}{c}7.08 \\
2\end{array}$ & \multirow{2}{*}{$\begin{array}{l}11 . \\
29\end{array}$} & \multirow{2}{*}{$<0.01$} \\
\hline & $\begin{array}{l}\text { Control } \\
\text { Group }\end{array}$ & 60 & 14.8 & $\begin{array}{c}7.52 \\
9\end{array}$ & & \\
\hline
\end{tabular}

3.3 Significant differences in visual thinking post-test for high achievers students

Mann-Whitney- U Test was used in order to measure the differences between mean scores of high achievers students in both groups at the visual thinking skills in the posttest. The results indicate significant differences in all the visual thinking skills in addition to the total degree $(p<0.001)$, except at the visual information interpreting skill that's no significant was found in it $(p=0.097)$. 
Table 3. Significant differences between high achievers students in the experimental and control groups in the visual thinking post-test

\begin{tabular}{|c|c|c|c|c|c|c|c|}
\hline $\begin{array}{c}\text { Visual } \\
\text { thinking } \\
\text { skills } \\
\end{array}$ & Group & $\mathbf{N}$ & $\begin{array}{c}\text { Mean } \\
\text { of } \\
\text { ord. }\end{array}$ & $\begin{array}{c}\text { Sum } \\
\text { of } \\
\text { ord. }\end{array}$ & $\begin{array}{c}\text { U } \\
\text { Val. }\end{array}$ & $\begin{array}{c}\mathbf{Z} \\
\text { Val. }\end{array}$ & $\begin{array}{c}p \\
\text { value } \\
\text { (sig.) } \\
\end{array}$ \\
\hline \multirow{2}{*}{$\begin{array}{l}\text { Shape } \\
\text { Recognition } \\
\text { Skill }\end{array}$} & $\begin{array}{l}\text { Exper. } \\
\text { Group }\end{array}$ & 16 & 24.38 & 390.0 & \multirow{2}{*}{2.0} & \multirow[t]{2}{*}{4.9} & \multirow{2}{*}{0.01} \\
\hline & $\begin{array}{l}\text { Control } \\
\text { Group }\end{array}$ & 16 & 8.63 & 138.0 & & & \\
\hline \multirow{2}{*}{$\begin{array}{l}\text { Visual } \\
\text { discrimination } \\
\text { skill }\end{array}$} & $\begin{array}{l}\text { Exper. } \\
\text { Group }\end{array}$ & 16 & 24.34 & 389.5 & \multirow[t]{2}{*}{2.5} & \multirow[t]{2}{*}{4.8} & \multirow[t]{2}{*}{0.01} \\
\hline & $\begin{array}{l}\text { Control } \\
\text { Group }\end{array}$ & 16 & 8.66 & 138.5 & & & \\
\hline \multirow{2}{*}{$\begin{array}{l}\text { Visual } \\
\text { information } \\
\text { interpreting } \\
\text { skill }\end{array}$} & $\begin{array}{l}\text { Exper. } \\
\text { Group }\end{array}$ & 16 & 18.75 & 300.0 & \multirow[t]{2}{*}{92.0} & \multirow[t]{2}{*}{1.6} & \multirow[t]{2}{*}{0.09} \\
\hline & $\begin{array}{l}\text { Control } \\
\text { Group }\end{array}$ & 16 & 14.25 & 228.0 & & & \\
\hline \multirow{2}{*}{$\begin{array}{l}\text { The spatial } \\
\text { relationship } \\
\text { recognize } \\
\text { skill }\end{array}$} & $\begin{array}{l}\text { Exper. } \\
\text { Group }\end{array}$ & 16 & 20.50 & 328.0 & \multirow{2}{*}{64.0} & \multirow{2}{*}{3.2} & \multirow{2}{*}{0.01} \\
\hline & $\begin{array}{l}\text { Control } \\
\text { Group }\end{array}$ & 16 & 12.50 & 200.0 & & & \\
\hline \multirow{2}{*}{$\begin{array}{l}\text { Shape } \\
\text { analysis skill }\end{array}$} & $\begin{array}{l}\text { Exper. } \\
\text { Group }\end{array}$ & 16 & 23.63 & 378.0 & \multirow{2}{*}{14.0} & \multirow[t]{2}{*}{4.5} & \multirow[t]{2}{*}{0.01} \\
\hline & $\begin{array}{l}\text { Control } \\
\text { Group }\end{array}$ & 16 & 9.38 & 150.0 & & & \\
\hline \multirow{2}{*}{$\begin{array}{l}\text { Recognize the } \\
\text { mystery and } \\
\text { decoding } \\
\text { optical } \\
\text { illusion skill }\end{array}$} & $\begin{array}{l}\text { Exper. } \\
\text { Group }\end{array}$ & 16 & 23.00 & 368.0 & \multirow{2}{*}{24.0} & \multirow{2}{*}{4.4} & \multirow{2}{*}{0.01} \\
\hline & $\begin{array}{l}\text { Control } \\
\text { Group }\end{array}$ & 16 & 10.00 & 160.0 & & & \\
\hline \multirow{2}{*}{$\begin{array}{l}\text { Construction } \\
\text { and } \\
\text { configuration } \\
\text { skill }\end{array}$} & $\begin{array}{l}\text { Exper. } \\
\text { Group }\end{array}$ & 16 & 22.00 & 352.0 & \multirow{2}{*}{40.0} & \multirow{2}{*}{3.9} & \multirow{2}{*}{0.01} \\
\hline & $\begin{array}{l}\text { Control } \\
\text { Group }\end{array}$ & 16 & 11.00 & 176.0 & & & \\
\hline \multirow{2}{*}{$\begin{array}{l}\text { Extracting } \\
\text { meanings } \\
\text { skill }\end{array}$} & $\begin{array}{l}\text { Exper. } \\
\text { Group }\end{array}$ & 16 & 23.63 & 378.0 & \multirow[t]{2}{*}{14.0} & \multirow[t]{2}{*}{4.5} & \multirow[t]{2}{*}{0.01} \\
\hline & $\begin{array}{l}\text { Control } \\
\text { Group }\end{array}$ & 16 & 9.38 & 150.0 & & & \\
\hline \multirow{2}{*}{ Total Scores } & $\begin{array}{l}\text { Exper. } \\
\text { Group }\end{array}$ & 16 & 24.50 & 392.0 & \multirow{2}{*}{0.00} & \multirow{2}{*}{4.8} & \multirow{2}{*}{0.01} \\
\hline & $\begin{array}{l}\text { Control } \\
\text { Group }\end{array}$ & 16 & 8.50 & 136.0 & & & \\
\hline
\end{tabular}

\subsection{Significant differences in visual thinking post-test for low achievers}

Mann-Whitney- U Test was used in order to measure the differences between mean scores of low achievers students in both groups at the visual thinking skills in the posttest. The results indicate significant differences in all the visual thinking skills in addition to the total degree $(\mathrm{p}<0.001)$
Table 4. Significant differences between low achievers students in the experimental and control groups in the visual thinking post-

\begin{tabular}{|c|c|c|c|c|c|c|c|}
\hline $\begin{array}{c}\text { Visual } \\
\text { thinking } \\
\text { skills } \\
\end{array}$ & Group & $\mathbf{N}$ & $\begin{array}{c}\text { Mean } \\
\text { of } \\
\text { ord. }\end{array}$ & $\begin{array}{c}\text { Sum } \\
\text { of } \\
\text { ord. }\end{array}$ & $\begin{array}{c}\mathbf{U} \\
\text { Val. }\end{array}$ & $\begin{array}{c}\mathbf{Z} \\
\text { Val. }\end{array}$ & $\begin{array}{c}p \\
\text { value } \\
\text { (sig.) }\end{array}$ \\
\hline \multirow{2}{*}{$\begin{array}{l}\text { Shape } \\
\text { Recognition } \\
\text { Skill }\end{array}$} & $\begin{array}{l}\text { Exper. } \\
\text { Group }\end{array}$ & 16 & 23.81 & $\begin{array}{c}381 . \\
0\end{array}$ & \multirow{2}{*}{11.0} & \multirow[t]{2}{*}{4.4} & \multirow{2}{*}{0.01} \\
\hline & $\begin{array}{c}\text { Control } \\
\text { Group }\end{array}$ & 16 & 9.19 & $\begin{array}{c}147 . \\
0\end{array}$ & & & \\
\hline \multirow{2}{*}{$\begin{array}{l}\text { Visual } \\
\text { discrimin- } \\
\text { ation skill }\end{array}$} & $\begin{array}{l}\text { Exper. } \\
\text { Group }\end{array}$ & 16 & 22.41 & $\begin{array}{c}358 . \\
0\end{array}$ & \multirow[t]{2}{*}{33.5} & \multirow[t]{2}{*}{3.6} & \multirow[t]{2}{*}{0.01} \\
\hline & $\begin{array}{l}\text { Control } \\
\text { Group }\end{array}$ & 16 & 10.59 & $\begin{array}{c}169 . \\
5\end{array}$ & & & \\
\hline \multirow{2}{*}{$\begin{array}{l}\text { Visual } \\
\text { information } \\
\text { interpreting } \\
\text { skill }\end{array}$} & $\begin{array}{l}\text { Exper. } \\
\text { Group }\end{array}$ & 16 & 22.38 & $\begin{array}{c}358 . \\
0\end{array}$ & \multirow[t]{2}{*}{34.0} & \multirow[t]{2}{*}{3.7} & \multirow[t]{2}{*}{0.01} \\
\hline & $\begin{array}{l}\text { Control } \\
\text { Group }\end{array}$ & 16 & 10.63 & $\begin{array}{c}170 . \\
0\end{array}$ & & & \\
\hline \multirow{2}{*}{$\begin{array}{l}\text { The spatial } \\
\text { relationship } \\
\text { recognize } \\
\text { skill }\end{array}$} & $\begin{array}{l}\text { Exper. } \\
\text { Group }\end{array}$ & 16 & 23.06 & $\begin{array}{c}369 . \\
0\end{array}$ & \multirow{2}{*}{23.0} & \multirow{2}{*}{4.1} & \multirow{2}{*}{0.01} \\
\hline & $\begin{array}{l}\text { Control } \\
\text { Group }\end{array}$ & 16 & 9.94 & $\begin{array}{c}159 . \\
0\end{array}$ & & & \\
\hline \multirow{2}{*}{$\begin{array}{l}\text { Shape } \\
\text { analysis } \\
\text { skill }\end{array}$} & $\begin{array}{l}\text { Exper. } \\
\text { Group }\end{array}$ & 16 & 21.31 & $\begin{array}{c}341 . \\
0\end{array}$ & \multirow[t]{2}{*}{51.0} & \multirow[t]{2}{*}{3.1} & \multirow[t]{2}{*}{0.01} \\
\hline & $\begin{array}{l}\text { Control } \\
\text { Group }\end{array}$ & 16 & 11.69 & $\begin{array}{c}187 . \\
0\end{array}$ & & & \\
\hline \multirow{2}{*}{$\begin{array}{l}\text { Recognize } \\
\text { the mystery } \\
\text { and } \\
\text { decoding } \\
\text { optical } \\
\text { illusion skill }\end{array}$} & $\begin{array}{l}\text { Exper. } \\
\text { Group }\end{array}$ & 16 & 24.13 & $\begin{array}{c}386 . \\
0\end{array}$ & \multirow{2}{*}{6.0} & \multirow{2}{*}{4.8} & \multirow{2}{*}{0.01} \\
\hline & $\begin{array}{c}\text { Control } \\
\text { Group }\end{array}$ & 16 & 8.88 & $\begin{array}{c}142 . \\
0\end{array}$ & & & \\
\hline \multirow{2}{*}{$\begin{array}{l}\text { Constructio } \\
\mathrm{n} \text { and } \\
\text { configuratio } \\
\mathrm{n} \text { skill }\end{array}$} & $\begin{array}{l}\text { Exper. } \\
\text { Group }\end{array}$ & 16 & 21.66 & $\begin{array}{c}346 . \\
5 \\
\end{array}$ & \multirow[t]{2}{*}{45.5} & \multirow[t]{2}{*}{3.6} & \multirow[t]{2}{*}{0.01} \\
\hline & $\begin{array}{l}\text { Control } \\
\text { Group }\end{array}$ & 16 & 11.34 & $\begin{array}{c}181 . \\
5\end{array}$ & & & \\
\hline \multirow{2}{*}{$\begin{array}{l}\text { Extracting } \\
\text { meanings } \\
\text { skill }\end{array}$} & $\begin{array}{l}\text { Exper. } \\
\text { Group }\end{array}$ & 16 & 23.06 & $\begin{array}{c}369 . \\
0\end{array}$ & \multirow[t]{2}{*}{23.0} & \multirow[t]{2}{*}{4.2} & \multirow[t]{2}{*}{0.01} \\
\hline & $\begin{array}{l}\text { Control } \\
\text { Group }\end{array}$ & 16 & 9.94 & $\begin{array}{c}159 . \\
0\end{array}$ & & & \\
\hline \multirow{2}{*}{ Total Scores } & $\begin{array}{l}\text { Exper. } \\
\text { Group }\end{array}$ & 16 & 24.5 & $\begin{array}{c}392 . \\
0\end{array}$ & \multirow{2}{*}{0.0} & \multirow{2}{*}{4.8} & \multirow{2}{*}{0.01} \\
\hline & $\begin{array}{l}\text { Control } \\
\text { Group }\end{array}$ & 16 & 8.50 & $\begin{array}{c}136 . \\
0\end{array}$ & & & \\
\hline
\end{tabular}

\section{DISCUSSION}

This study used the pre-post test design to determine the effectiveness of using the computerized interactive book in the development of visual thinking skills in Technology for the fifth grade male students in Gaza. No significant differences were found between the experimental and control groups in the visual thinking pretest results in addition to no significant differences were found between mean scores of high achievers at the experimental and control groups in the visual thinking pretest, also there is no significant differences were found between mean scores of low achievers at the experimental and control groups in the visual thinking pretest.

The computerized interactive book has benefited all students in different levels; because it helped high achievers students develop their skills and abilities and encourage them to selfeducation, also helped low achievers students continue the learning process just like other students. 
The positive results of this study were not a coincidence, Due to many factors, the most important is: The information is taken in or perceived by senses such as sight, smell, hearing, or a combination of these[13]. All the scenes that go through the sight sense helps students to begin the visual thinking.

In addition, visual representations help students elaborate on knowledge by adding to or elaborating on knowledge, students understand it better, as well as being better able to remember it [14].Visual thinking is complex, rich, textured, detailed and imaginative. With visual thinking the information is processed instantly, just by looking at a picture.[15]. Proponents of visual literacy maintain that students of all ages who engage in these sustained, art process oriented experiences cultivate creativity and risk-taking while reinforcing critical thinking and communication skills[16].

Arguably in everyday life, visual information is part of the way we interpret experience and build understanding. This can be illustrated in three ways. First, visual information is part of the information with which we reason, such as extraction of information from a map, chart or table and representing and expressing it in language. Second, visual thinking can be integral to problem solving, as when we need to use a diagram to explain, document, calculate or show the steps involved in reaching a solution. Third, visual representation can play a role in synthesizing information or in identification of concepts as when we need to use diagrammatic and visual forms to communicate information, represent data and show relationships[17].

The computerized interactive book gives opportunities of discovery to find new ways in the interaction with information because it's a media format that contains audio, image, film, with interactive multimedia connections which can be $\mathrm{read} /$ watched in computers and similar devices [18]. Moreover the students were able to listen to the text, change the font size and take notes and these extras led to a better understanding of the book contents[10]. In addition to the integration between the computerized interactive book and the different teaching strategies used by teacher in the classroom contributed to increase the success of the computerized interactive book in achieving the objectives of the study up to these results.

Motivation to read is one of the essential elements for actively engaging children in the reading process and is an important component for all students to be successful in school[19]. Many studies confirmed that the computerized interactive book has the ability to develop attitudes toward reading such as Jeong study which declared that the students expressed that e-books are useful reading devices. Most students reported that the e-book was easy to read. For example, regarding the e-books' usefulness, they found that the font size and type were easy to read, that the screen sequence was clear, and that the tasks of scrolling up and down, moving pages, and finding information were easy and convenient[20].

\section{CONCLUSION}

The findings in this study indicated that there is effectiveness of the computerized interactive book in developing the visual thinking skills, and this contributes to the growing of the conviction of the importance of the computerized interactive book, and supports using it in education, not only the high achievers students are the beneficiaries ,but the low achievers students too.
The learning strategies used by teachers in the classroom increases the effectiveness of the computerized interactive book in education.

\section{REFERENCES}

[1] Farajallah, A. \& Al arjani, S. 2012 The Obstacles of using Computerized Interactive Learning in the Teaching of Mathematics from the Teachers' Perspective at UNRWA Schools in Gaza Strip Governorates, International Journal of Computer Applications, 52(3), pp. 43-51.

[2] Huang, Y. ; Liang, T. ; Su, Y. ; Chen, N.2012 Empowering Personalized Learning with an Interactive E-Book Learning System for Elementary School Students, Educational Technology Research and Development, 60(4), pp. 703-722 .

[3] Robb, M. 2010 New Ways of Reading: The Impact of an Interactive Book on Young Children's Story Comprehension and Parent-Child Dialogic Reading Behaviors, Ph.D. Dissertation, University of California. [Online] Available from: http:// http://eric.ed.gov/ [Accessed 7-1-2014].

[4] Mitropoulou, V 2012 Interactive books for primary and secondary education for the course of religion in Greece, IADIS International Conference on Cognition and Exploratory Learning in Digital Age (CELDA 2012).

[5] Jones. T \&Brown, C 2011 Reading Engagement: A Comparison Between E books And Traditional Print Books In An Elementary Classroom, International Journal of Instruction, 4(2).

[6] PC magazine encyclopedia, e-book ,[online] Available from: http://www.pcmag.com/encyclopedia/term/42214/e-book [Accessed 8-1-2014].

[7] Živkovic, D 2008 The Electronic Book: Evolution or Revolution?, Bilgi Dünyası (World of Knowledge),9(1), pp. 1-19.

[8] Cheng, J , Huang, E , \& Lin, C 2012 An E-Book Hub Service Based on a Cloud Platform, The International Review Of Research In Open And Distance Learning. [Online] Available from: http://eric.ed.gov/fulltext/EJ1001721.pdf [Accessed 81-2014].

[9] Baki, A. \& Ongoz, S. 2010 E-Book Usage Of Graduate Students Studying Educational Sciences In Turkey, Turkish Online Journal of Distance Education-TOJDE, 11(1).

[10] Pledger, P. 2010Future of the Book? Challenge of the Digital World, International Association of School Librarianship, [Online] Available from: http://eric.ed.gov/?id=ED518513 [Accessed 12-1-2014].

[11] Grandin, T. 2006Thinking in Pictures, [Online] Available from: http://www.grandin.com/inc/visual.thinking.html [Accessed 12-1-2014].

[12] Palestinian ministry of education. [Online] Available from: http://www.mohe.gov.ps/Uploads/admin/Statistical\%20B ook\%20final.pdf [Accessed 7-1-2014]. 
[13] Kissinger, J 2011The social \& mobile learning experiences of students using mobile e-books, Journal of Asynchronous Learning Networks, 17 (1),PP 155-170.

[14] Plough, J 2004 Students Using Visual Thinking to Learn Science in a Web-based Environment, doctoral dissertation, Drexel University, Philadelphia, USA.

[15] Sword, L. 2005 THE POWER OF VISUAL THINKING Gifted \& Creative Services Australia. [Online] Available from:

http://www.giftedservices.com.au/visualthinking.html [Accessed 12-1-2014].

[16] Landorf, H. 2006 What's going on in this picture? Visual thinking strategies and adult learning, New Horizons in Adult Education and Human Resource Development,20 (4). PP 28-32.

[17] McLoughlin, C 1997 Visual Thinking and Telepedagogy, The Australian Society for Computers in Learning in
Tertiary Education (ASCILITE) conference ,December 7-10. [Online] Available from: http://www.ascilite.org.au/conferences/perth97/papers/M cloughlin/Mcloughlin.html [Accessed 12-1-2014].

[18] Hatipoglu, N \& Tosun, N 2012 The Design Of Renewable And Interactive E-Book Template For ELearning Environments, Online Journal of Communication and Media Technologies,2(2).

[19] Ciampa, K. 2012 Reading in the Digital Age: Using Electronic Books as a Teaching Tool for Beginning Readers, Canadian Journal of Learning and Technology, Vol. 38, No 2 .

[20] Jeong, H. 2012 A comparison of the influence of electronic books and paper books on reading comprehension, eyefatigue, and perception, The Electronic Library, 30(3). , [Online] Available from: www.emeraldinsight.com/0264-0473.htm [Accessed 131-2014] 